\title{
Vulnerability level of target and by-catch species on tuna hand line (HL-TR) fishery in Indonesian Fisheries Management Area I-FMA 573 based at Sadeng Fishing Port
}

\author{
Regi Fiji Anggawangsa ${ }^{1}$, Agustinus Anung Widodo ${ }^{1 *}$, Wudianto ${ }^{1}$, Ignatius Tri Hargiyatno ${ }^{1}$, \\ Lilis Sadiyah ${ }^{1}$, Mahiswara ${ }^{2}$, Fayakun Satria ${ }^{2}$ \\ ${ }^{1}$ Center for Fisheries Research \\ ${ }^{2}$ Research Institute for Marine Fisheries
}

\begin{abstract}
Tuna hand line-trolling line (HL-TR) fisheries have an essential role in Indonesia's tuna fisheries, including Indonesia Fisheries Management Areas (I-FMAs) 572 and 573. The catch of tuna line in I-FMA 572 and 573 reached $\sim 30.4 \%$ of the total catch 189,022 tonnes in 2019 . Limited data and scientific advice for developing adequate management remain a challenge for tuna HL-TR fisheries in I-FMA 573 waters. Center for Fisheries Research (CFR) has conducted an assessment using the PSA method to obtain information of vulnerability level both of target and bycatch species on tuna HL-TR in 2020. Data used in the analysis were grouped into operational fishing, productivity, and susceptibility data. The operational fishing data were obtained from Sadeng Fishing Port in2019. The productivity and susceptibility data were obtained from literature review and expert consultation through a Focus Group Discussion (FGD) and expert consultative workshop. The result showed that both target and by-catch species included in the analysis have low to moderate vulnerability level scores. The results of this research are used to help managers at a national level to determine necessary management measures with high precautionary. While for by-catch species, in particular white tip sharks, its management measures must comply with agreed IOTC regulations.
\end{abstract}

\section{Introduction}

Tuna fisheries in Indonesia Fishing Management Areas (I-FMA) 572 and 573 consists of longline tuna (LL), purse seine (PS), drifting gillnet (d-GN), and lines fisheries.Thelines fisheries here mainlyrefer to several tuna fishing gears, including hand line (HL), trolling line (TR), kite line (KL), and vertical line (vL) fishery[1]. Lines fisheries are hereafter called HLTR tuna fisheries, and the boat operates the HL-TR gear, also called HL-TR boat. The HLTR fisheries in the FMA 572 and 573have been developed since the mid-2000s [2-5]. A HLTR boat operates several gears in every fishing trip, including HL, TR, KL, and vL gear. Fishers of HL-TR boats switch the fishing gears depending on the season, sea conditions, and

*Corresponding author : anungwd@yahoo.co.id 
catch success [6]. The HL-TR tuna fisheries have an essential role in tuna fisheries in Indonesia. Fisheries Management Area (I-FMA) 572 and 573 with catch reaching $~ 30.4 \%$ of total catch 189,022 tonnes in 2019 [7]. Results observation in I-FMA 573 in 2019 [1] identified that the HL-TR tuna fishery has two characters which are also outstanding issues were: (1) high diversity of fish species of catch including target and by-catch, (2) limited data and information available. The high diversity of fish species has shown on the HR-TR boats based in Cilacap fishing port which landed at least 28 species of catch, both tuna as a target and by-catch, included in the ecologically related species (ERS) such as sharks and rays [8]. The marine fish genera and species per genera peak around the equator (tropical waters) and decline towards the poles [9].

Ecological risk assessments (ERA) that elaborate productivity and susceptibility analysis (PSA) are commonly used to assess vulnerability where the by-catch data are minimal. The exposure relates to the possibility that a population, community, or habitat will experience significant change from a short-term or long-term disruption, and the possibility that it will get back (recover) and in what time frame. These are also linked to the type of the ecosystem itself, specifically the biological and structural aspects. The most vulnerable ecosystems are characterized by being easily disturbed and slow to get back, or even not ever being able to get back [10]. Productivity and susceptibility analysis is used to assess the species vulnerability that is accidentally captured on three net setting types: dolphin sets, free schooling fish sets, and flotsam sets of tuna PS fishery operating in the eastern Pacific Ocean (EPO) [11]. In Indonesia itself, at least two scientific papers used the PSA approach to assess tuna fisheries, i.e., Sadiyah et al. and Suryaman et al. [12,13]. To determine the vulnerability level of the target and by-catch species on tuna HL-TR fishery in Indonesia Fisheries Management Area (I-FMA) 573, especially in the south of Java, the Center for Fisheries Research (CFR) was researched Sadeng Fishing Port in 2020. Due to the limitation of data available, PSA is considered a good approach to assess the vulnerability level of target and by-catch species of the HL-TR tuna boats operating in the I-FMA 573 and based at Sadeng Fishing Port.

\section{Materials and Methods}

\subsection{Materials}

The data and information used in this paper are part of the data collected in research on smallscale fisheries of tuna associated with fish aggregating devices in the I-FMA 573 southern of Java' which was conducted and funded by the Center for Fisheries Research (CFR) in 2020. This research was conducted in Sadeng fishing port focused on fisheries of tuna HLTR (Figure 1 presents the research location). Duffy et al. [11] suggested the criteria of species were included out of the productivity and susceptibility analysis work, assuming that the catch of a species created more than $0.05 \%$ from the whole of by-catch in any year and more than $5.0 \%$ of the net for the whole type of set. The fish species assessed in the current study include skipjack tuna, yellowfin tuna, bigeye tuna, kawa-kawa, longtail tuna, dolphinfish, rainbow runner, black marlin, and the silky shark. Furthermore, the FAO species codes, namely SKJ, BET, BET, KAW, LOT, DOL, RRU, BLM, and FAL, refer to those fish species, respectively. 


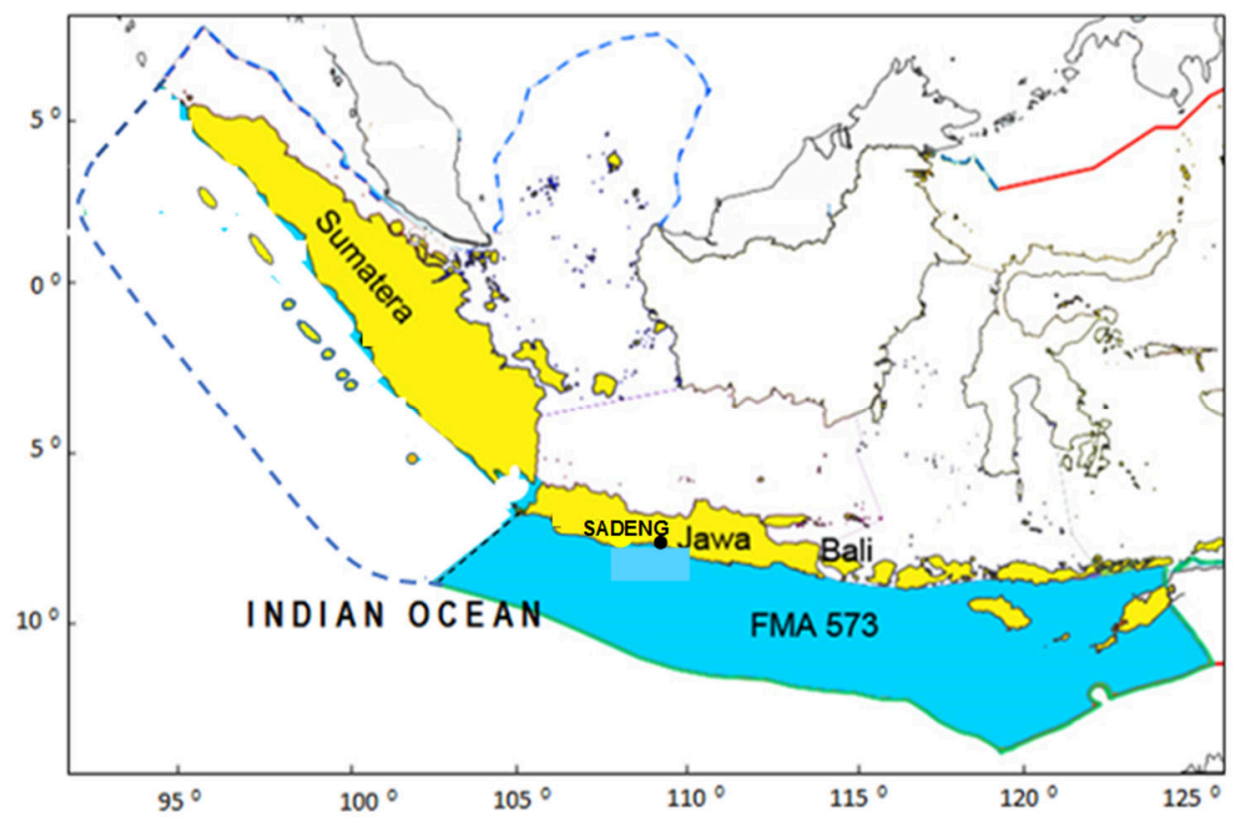

Fig. 1. Map of the location of data collection (Sadeng Fishing Port) and I-FMA 573.

The data and information were grouped into fishing operational aspects (number of a fishing trip, catch, catch composition, etc.), productivity and susceptibility. Fishing functional is landing data of HL-TR boats in 2019 were obtained from Sadeng Fishing Port. Stobutzki et al. [14] mentioned that a stock capability to get back from a state of depletion is used to define productivity. The possibility of species to catch and mortality of the fishery is used to determine susceptibility. Age and maturity, maximum of age, fecundity, maximum size, mature size, the strategy of reproduction, and tropic level are considered attributes of productivity. Data and information of the productivity attribute were obtained through a literature study including fish base [15] and scientific papers, which are relevant in this study. Table 1 presents the literature reviewed to get information on the productivity attributes of the species assessed in this study. 
Table 1. The kinds of literature reviewed to obtain information of the productivity attributes of the species which are assessed.

\begin{tabular}{|c|c|}
\hline Fish Species & Sources \\
\hline SKJ & Matsumoto et al. and Tampubolon et al. $[16,17]$ \\
\hline YFT & Wujdi et al., Koya, et al. and Reyes et al. [18-20] \\
\hline BET & Mimura et al., Fauziah et al. and Setyadji et al. [21-23] \\
\hline KAW & Arnenda et al. and Johnson et al. $[24,25]$ \\
\hline LOT & Wagiyo et al. and Griffiths et al. $[25,27]$; \\
\hline DOL & Mudumala et al. and Martínez-Ortiz et al. [28,29] \\
\hline RRU & Yesaki and Schwartz [30,31]; \\
\hline BLM & Nakamura and Williams $[32,33]$ \\
\hline FAL & Dharmadi et al. and Murua et al. $[34,35]$. \\
\hline
\end{tabular}

Data and information of susceptibility attributes were obtained from reviews of relevant pieces of literature, including IOTC https://iotc.org/node/3379, Setyadji, et al., Thompson et al.; Wibowo et al., [37-40]. The data information was also obtained from the result of focus group discussion (FGD) and consultation with scientists and experts from Center Fisheries Research (CFR), Research Institute for Marine Fisheries (RIMF), and managers or officers under the Directorate General of Capture Fisheries (DGCF).

\subsection{Methods}

This study uses PSA, which NOAA developed; species vulnerability to the fishing impacts is calculated by evaluating the productivity and susceptibility of a stock. A score of one to three is given for high to low productivity; respectively; otherwise, a score of 3 to 1 is provided for high to low susceptibility, respectively. Equation 1 [36] is used to calculate the vulnerability.

$$
v=\sqrt{(p-3)^{2}+(s-1)^{2}}
$$

where $v=$ vulnerability $p=$ productivity score and $s=$ susceptibility score.

The most invulnerable species is reflected by high productivity and a low susceptibility score, and vise versa the most vulnerable species indicated by having low productivity and having high susceptibility score and PSA result is also graphically displayed (Patrick et al., 2009) [36]. Scores of vulnerability level $(v)$ ranged from low to very high, $v$ is low when the $v<1.8$, moderate $(2.0<v>1.8)$, high $(2.2<v>2.0)$ and very high $(v>2.2)$. Quality of data (DQ) score was also assigned to both attributes productivity and susceptibility to describe the reliability of the data source and provide an estimate of uncertainty and (Table 2) present detail of DQ scoring $[36,14]$. 
Table 2. Detail of data quality (DQ) scoring for analysis.

\begin{tabular}{|c|l|}
\hline DQ scores & \multicolumn{1}{c|}{ Indications } \\
\hline DQ1 & $\begin{array}{l}\text { Best data is the result of data collection of the stock and area interest that is } \\
\text { established and substantial. }\end{array}$ \\
\hline DQ2 & $\begin{array}{l}\text { adequate data, data is from on finite coverage and corroboration, or for some } \\
\text { other reason is deemed not as reliable as tier-1 data. }\end{array}$ \\
\hline DQ3 & $\begin{array}{l}\text { finite data estimates with high variation and limited confidence and maybe } \\
\text { from on research of similar taxa or life strategies of history, }\end{array}$ \\
\hline DQ4 & $\begin{array}{l}\text { finite data, data from on judgment of expert or literature studies from a wide } \\
\text { range of species, or outside of the area }\end{array}$ \\
\hline DQ5 & no data. \\
\hline
\end{tabular}

\section{Results}

\subsection{Profile of Hand Line Tuna Fishery Based at Sadeng Fishing Port}

Fishers of tuna hand line based at Sadeng fishing port use multi-gear boats referred to as HLTR boats. In general, the boats catch tuna in the around of the fish aggregating devices (FADs). The HL-TR boats are commonly wooden hulls of size $<10$ GT with 3-5 crews. In every fishing trip, a HL-TR boat typically uses multi-gear, including deep tuna hand line (d$\mathrm{HL}$ ), surface tuna hand line (s-HL), trolling line (TR), kite line (KL), vertical line (vL), and surface gillnet (s-GN), even small pelagic fishing gears such as small pelagic hand line (spHL), hairtail hand line (h-HL) and squid angler (SA) as illustrated in Figure 2. Furthermore, Table 3 presents the brief characteristic of each gear operated by HL-TR boats. The fishing gears are used alternately depending on the season, seas conditions, and fish target.

Analysis of 604 landings data of tuna HL-TR boats based at Sadeng fishing port during 2019 show that the total catch reached 690,78 tonnes, the average catch $\sim 10$ tonnes per boat per year, and the catch rate $\sim 0.207$ tonnes per active boat per day. Table 4 presents the Summary of tuna HL-TR fishing operational in I-FMA 573 based at Sadeng fishing port in 2019.

At least 12 fish species were recorded caught by tuna HL-TR boats based at Sadeng fishing port in 2019 that dominated by SKJ reached $328,624 \mathrm{~kg}$ or $\sim 47.6 \%$ of the total catch (Table 5). SKJ is usually caught when the HL-TR vessel operates the surface HL (s-HL) or trolling line (TR). 


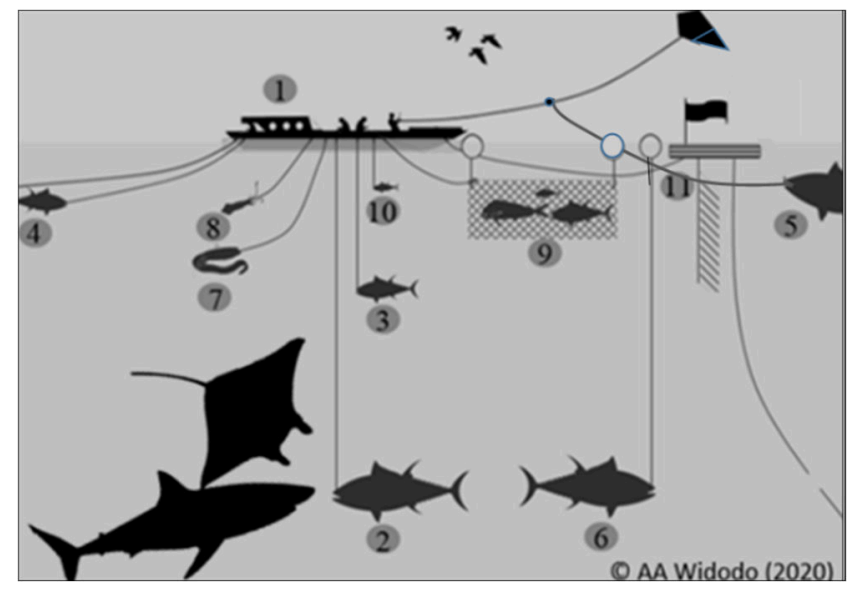

Fig. 2. Illustration of the multi-gears that are operated by (1) a HL-TR boat on every fishing trip includes (2) d-HL, (3) s-HL, (4) TR, (5) KL (6) vL, (7) h-HL, (8) SA, (9) s-GN (10), sp-HL, (11) FAD [8].

Table 3. Brief information of each gear characteristic operates by HL-TR based at Sadeng Fishing Port.

\begin{tabular}{|c|c|c|}
\hline Gear types & Specification & Species target \\
\hline $\begin{array}{l}\mathrm{d}-\mathrm{HL} \\
\text { (deep handline) }\end{array}$ & $\begin{array}{l}\text { Hooks size no. } 7 / 0-8 / 0 \text {, bait: the whole of } \\
\text { small pelagic fish with size } \sim 150-300 \mathrm{~g} / \text { fish } \\
\text { (dead or live) or piece of fish } \sim 150-200 \\
\text { g/piece. }\end{array}$ & $\begin{array}{l}\text { Large YFT and large } \\
\text { BET size }>70 \mathrm{~cm} \mathrm{FL}\end{array}$ \\
\hline $\begin{array}{c}\mathrm{s}-\mathrm{HL} \\
\text { (surface handline) }\end{array}$ & $\begin{array}{c}\text { Hooks size: no. } 3 / 0-4 / 0 \text {, bait: juvenile of } \\
\text { small pelagic fish size } \sim 30-50 \mathrm{~g} / \text { fish or piece } \\
\text { of fish with } \sim 30-50 \mathrm{~g} / \text { piece or fake bait } \\
\text { (lure) } .\end{array}$ & $\begin{array}{l}\text { SKJ, j-YFT, j-BET, } \\
\text { neritic tuna and } \\
\text { sheerfish }\end{array}$ \\
\hline $\begin{array}{c}\mathrm{TR} \\
\text { (trolling line) }\end{array}$ & Hook size no. $3 / 0-4 / 0$, with fake bite (lure). & $\begin{array}{l}\text { SKJ, j-YFT, j-BET, } \\
\text { neritic tuna, and } \\
\text { sheerfish }\end{array}$ \\
\hline $\begin{array}{c}\mathrm{KL} \\
\text { (kite line) }\end{array}$ & $\begin{array}{l}\text { Hook size no. } 7 / 0-8 / 0, \text { with bait whole of } \\
\text { small pelagic fishes size } \sim 150-300 \mathrm{~g} / \text { fish }\end{array}$ & $\begin{array}{l}\text { Large YFT, large BET, } \\
\quad \text { and large billfish }\end{array}$ \\
\hline $\begin{array}{c}\mathrm{vL} \\
(\text { vertical line })\end{array}$ & $\begin{array}{l}\text { Hook size no. } 7 / 0-8 / 0, \text { with the whole of } \\
\text { small pelagic fish size } \sim 150-300 \mathrm{~g} / \text { fish or } \\
\text { piece of size } \sim 150-200 \mathrm{~g} / \text { piece. }\end{array}$ & $\begin{array}{l}\text { Large YFT and large } \\
\text { BET (size }>70 \mathrm{~cm} \mathrm{FL)}\end{array}$ \\
\hline $\begin{array}{l}\mathrm{h}-\mathrm{HL} \\
(\text { hair-tail } H L)\end{array}$ & $\begin{array}{l}\text { Hook size no. 1/0, bait: juvenile of small } \\
\text { pelagic fishes size } \sim 30-40 \text { gram /fish or } \\
\text { piece of small pelagic fishes size } \sim 30-40 \\
\text { g/piece. }\end{array}$ & Hairtail fishes \\
\hline $\begin{array}{l}\text { SA } \\
\text { (squid angler) }\end{array}$ & Use specific hooks with lure bait. & Squids \\
\hline
\end{tabular}




\begin{tabular}{|c|c|c|}
\hline $\begin{array}{c}\text { s-GN } \\
\text { (surface drift gillnet) }\end{array}$ & $\begin{array}{c}\text { Multi or monofilament net } \sim 3 \text { piece/set and } \\
\text { mesh size \# 2 inch }\end{array}$ & $\begin{array}{c}\text { Small pelagic for bait of } \\
\text { d-HL,s-HL, and KL }\end{array}$ \\
\hline sp-HL & $\begin{array}{c}\text { Hook size no. 1/0, bait: a piece of fish size } \sim \\
10-20 \text { g/piece or lure. The lure is usually a } \\
\text { plastic feather or a metallic small part of thin } \\
\text { sink or aluminum plat (used soft drink cans). }\end{array}$ & $\begin{array}{c}\text { Small pelagic for bait of } \\
\text { d-HL,s-HL, and KL }\end{array}$ \\
(small pelagic HL) & \\
\hline
\end{tabular}

Table 4. Summary of tuna HL-TR fishing operational in FMA 573 based at Sadeng Fishing Port in 2019.

\begin{tabular}{cc}
\hline Characteristic of Fishing Boats & Indicators \\
\hline Number of active HL-TR boats & 66 boats \\
Hull material and size (GT) & Wooden boat and $<10 \mathrm{GT}$ \\
Main engine & $30 \mathrm{HP}$ \\
Number of crew & $4-5$ crews \\
Number of landings or fishing trip & $\sim 604$ fishing trips \\
Day at sea per fishing trip & $\sim 3-7$ (average 4,5$)$ days \\
Total day at sea of all active boats & $\sim 2670$ days \\
Day at sea per active vessel per year & $\sim 3-134$ (average 40,5) days \\
Total catch of HL-TR (active boat) & $\sim 690,78$ tonnes \\
Catch per boat per year & $\sim 10$ tonnes \\
Catch rate (CR) & $\sim 0.207$ tonnes per active boat per day
\end{tabular}

Table 5. Species composition of tuna HL-TR catch boats based at Sadeng fishing port in 2019

\begin{tabular}{ccccc}
\hline Common Name & Scientific Name & FAO Code & Volume (KG) & $\%$ \\
\hline Skipjack tuna & Katsuwonus pelamis & SKJ & 328624 & 47.6 \\
Yellowfin tuna & Thunnus albacares & YFT & 120325 & 17.4 \\
Bigeye tuna & Thunnus obesus & BET & 35410 & 5.1 \\
Kawa-kawa & Euthynnus affinis & KAW & 46894 & 6.8 \\
Dolphin-fish/mahimahi & Coryphaena hippurus & DOL & 35540 & 5.1 \\
Longtail tuna & Thunnus tonggol & LOT & 16142 & 2.3 \\
Black marlin & Makaira indica & BLM & 11927 & 1.7 \\
\hline
\end{tabular}




\begin{tabular}{ccccc}
\hline Silky shark & Carcharhinus falciformis & FAL & 7313 & 1.1 \\
Rainbow-runner & Elagatis bipinnulata & RRU & 6482 & 0.9 \\
$\begin{array}{c}\text { Narrow-barred Spanish } \\
\text { mackerel } \\
\text { Other }\end{array}$ & Scomberomorus commerson & COM & 821 & 0.1 \\
\hline
\end{tabular}

\subsection{Vulnerability of Catch}

The result of PSA shows that the vulnerability of selected species in the current study includes SKJ. YFT, BET DOL, RRU BLM, KAW, LOT, and FAL caught by tuna HL-TR boats based at Sadeng fishing port in 2019 are in the low and moderate level range (Table 6) with data quality (DQ) 3-5. As targets species, YFT and BET have an average level of vulnerability, and SKJ has a low vulnerability. By-catch species of HL-TR fishery in Sadeng have a low rate of exposure. The graph of the PSA result is displayed in Figure 3.

Table 6. A score of productivity, susceptibility, and level of vulnerability and tuna HL-TR's catch based at Sadeng Fishing Port.

\begin{tabular}{ccccc}
\hline Fish Species & $\begin{array}{c}\text { A score of } \\
\text { productivity }(p)\end{array}$ & $\begin{array}{c}\text { A score of } \\
\text { Susceptibility }(s)\end{array}$ & $\begin{array}{c}\text { Vulnerability } \\
\text { level }(v)\end{array}$ & Concern \\
\hline Skipjack tuna (SKJ) & 1.45 & 1.88 & 1.78 & low \\
Yellowfin tuna (YFT) & 1.71 & 2.33 & 1.85 & moderate \\
Bigeye tuna (BET) & 1.57 & 2.33 & 1.95 & moderate \\
Kawa-kawa (KAW) & 2.39 & 2.35 & 1.48 & low \\
Dolphinfish (DOL) & 1.57 & 1.43 & 1.49 & low \\
Longtail tuna (LOT) & 2.58 & 1.80 & 0.90 & low \\
Black marlin (BLM) & 2.14 & 2.18 & 1.46 & low \\
Silky shark (FAL) & 2.71 & 1.88 & 0.93 & low \\
Rainbow runner (RRU) & 1.57 & 1.58 & 1.54 & low \\
\hline
\end{tabular}




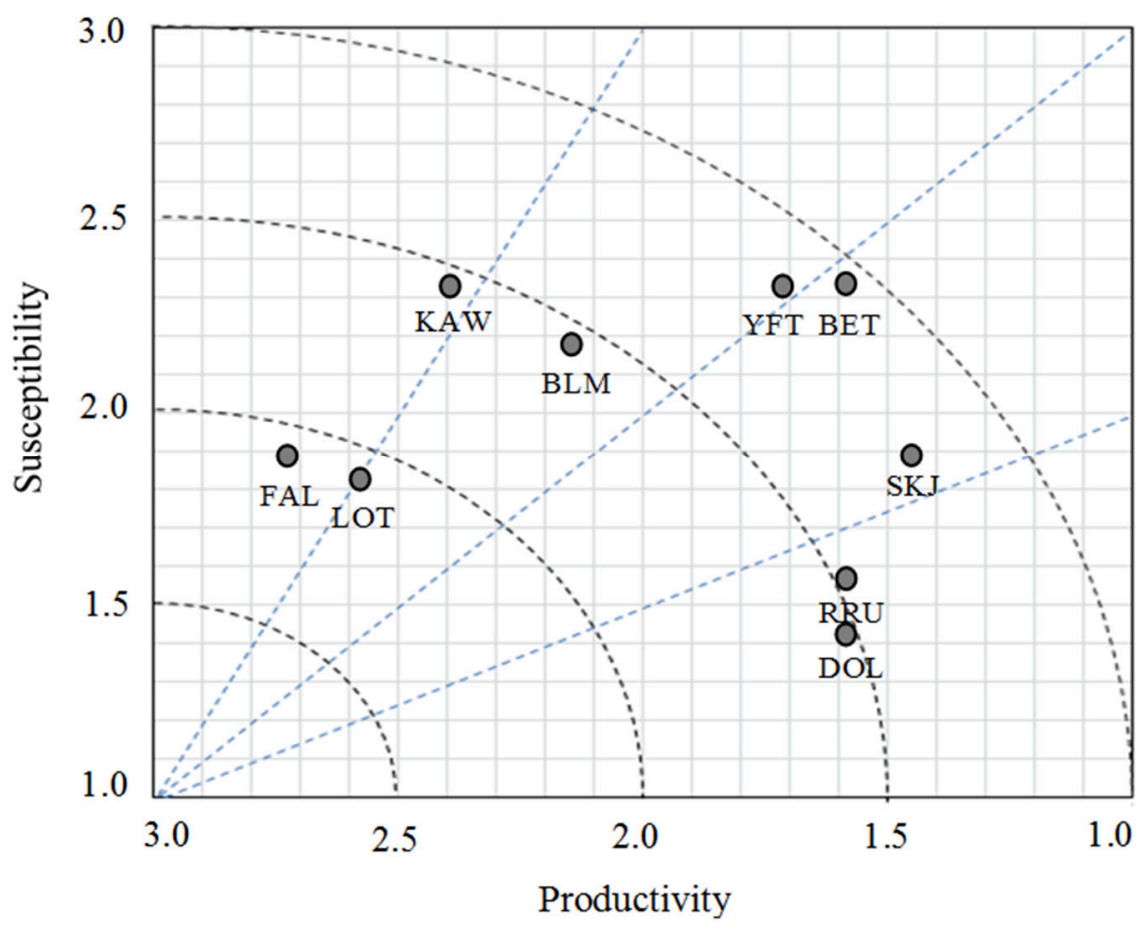

Fig. 3. The graph of the PSA result was conducted for target and by-catch species of tuna HL-TR boats based at Sadeng fishing port.

\section{Discussion}

YFT and BET have a moderate vulnerability level, while other species have a low level of vulnerability. Hobday et al.[42] proposed productivity and susceptibility analysis as a $2^{\text {nd }}$ level analysis of the three-level hierarchical Ecological Risk Assessment for the effects of Fishing framework. The typical vulnerable species are taken out. The species with high vulnerability are subjected to a management response, including specific mitigation threats or data collection improvement, to reassess the following non-qualitative $3^{\text {rd }}$ level analysis. Even though the results of the stock assessment in the Indian Ocean show that the stock of YFT is determined to remain overfished and subject to overfishing, and the supply of BET is determined to be not overfished but subject to overfishing [37], but the species not vulnerable by the fish using HL-TR fishing gear. Tuna HL-TR includes in the selective fishing gear category $[38 ; 40]$ and allows the equipment not to result in a high level of vulnerability to either the target species or by-catch even if the species is experiencing overfished and overfished.

As initial scientific evidence, the results of this research can be used to help determine management measures with high precautionary. Need to improve the data quality (DQ), including the productivity and susceptibility attributes. Lack of operational fishing data and serial data, including the number of catches, effort, catch composition, fish size, and biological and life history aspects, occur in this fishery. These issues need to be addressed to fully understand the impact of fishing operations on each species in the current research. Data collection programs including port sampling, logbooks, and observer programs enable data needs to be fulfilled. An issue that should also get more attention is the capture of silky sharks. 
Management, including mitigation and handling of shark including sharks, must comply with regulations issued by both national and tuna RFMOs in the Indian Ocean, including IOTC and CCSBT.

\section{Conclusion}

The PSA results showed that both target and by-catch species do not have a high vulnerable level to fishing using tuna HL-TR. The results of this research can be used to help managers determine management measures with high precautionary. Another critical issue that should also get more attention is the capture of silky sharks. Its management measures must comply with regulations that have been issued nationally and RFMO (IOTC). The lack of operational fishing and serial data includes the number of catches, effort, catch composition, fish size, and biological. Life history aspects are outstanding issues in tuna HL-TR fishery based at Sadeng fishing port. These issues need to be addressed through data collection programs, including port sampling, logbook, and observer programs in the future.

\section{Acknowledgment}

Statement, All authors are main contributors in this paper include Regi F. Anggawangsa, Agustinus Anung Widodo, Ignatius Tri Hargiyatno, Lilis Sadiyah,, Mahiswara, Fayakun Satria and Wudianto.The authors wish to thank the support of CFR's research and parties in this research, including the head and staff of Sadeng Fishing Port, who assisted, data from landing activities in 2012, and facilities during a field trip in Sadeng Fishing Port. Thanks to all participants of FGD and expert consultative workshop, Mr. Rudi Masuswo (CFR), Dr. Erfind Nurdin (RIMF), Ms. Putuh Suadela (DGCF), Mr. Hary Kristianto (DGCF), Mr. Wargiatno (Sadeng F.P.), and Mr. Abdul Iman (Prigi F.P.) for their input and expertise.

\section{References}

1. A. A.Widodo, Wudianto, I. T. Hargiyatno, Suryanto, R. T. Mahulette, S. Wibowo, L. Sadiyah, Wijopriono, A. A. Akbar, R. Fauziah, F. Satria \& Z. Fahmi, Kajian Perikanan Tuna Skala Kecil yang Berasosiasi dengan Rumpon di Perairan Selatan Jawa (WPPNRI 573) (Unpublished Report, 2020)

2. M. Nuramin, Undergraduate Thesis. Bogor (ID): Institut Pertanian Bogor (2005)

3. A. Ross, Undergraduate Thesis. Bogor (ID): Institut Pertanian Bogor (2008)

4. A. Ross, E. S. Wiyono, T. W. Nurani, Buletin PSP. 20, 3 (2012)

5. I. T Hargiyatno, R. F. Anggawangsa, Wudianto, J. Penelit. Perikanan Indonesi., 19, 3 (2013)

6. A. A. Widodo, Wudianto, L. Sadiyah, Mahiswara, C. Proctor, S. Cooper, Indones.fish res. J., 26, 2 (2020)

7. Z. Fahmi, Y. Hikmayani, T. Yunanda, P. Yudiarso, Wudianto, B. Setyadi, IOTC-2020SC23-NR07, Indonesia National Report to the Scientific Committee of the Indian Ocean Tuna Commission 2020 (IOTC, Ministry of Marine Affairs and Fisheries of Republic Indonesia, 2020).

8. I. T. Hargiyatno, L. Sadiyah \& A. A. Widodo. Risk assessment of vulnerability on ecological related species (ERS) based in Cilacap. Presented on Simposium Hiu dan Pari di Indonesia Ke-3 tahun 2021 ( ${ }^{\text {rd }}$ Shark and Rays in Indonesia Symposium 2021) (Unpublished Report, 2021) 
9. P. T. Rajan. Marine Fishery Resources and Species Diversity of Tropical Waters. Biodiversity and Climate Change Adaptation in Tropical Islands (Amsterdam, Elseiver Science Publisher, 2018)

10. FAO International Guidelines for the Management of Deep-sea Fisheries in the High Seas (FAO, Rome, 2009)

11. L. M. Duffy, C. E. Lennert-Cody, R. J. Olson, C. V. Minte-Vera, Fish Res (2019)

12. L. Sadiyah, F. Satria, I. T. Hargiyatno, A. A. Widodo, IOP Conf. Series: Earth and Environ. Sci. 404 (2019)

13. E. Suryaman, M. Boer, L. Adrianto. L, Sadiyah, J. Penelit. Perikanan Indonesi., 23, 1 (2017)

14. I. Stobutzki, M. Miller, D. Brewer, Environ Conserv, 28, 2 (2001)

15. R. Froese, D. Pauly, Fishbase World Wide Web Electronic Publication, www.fishbase.org (2021)

16. W. M. Matsumoto, R. A. Skiliman, A. E. Dizon, Synopsis of Biological Data on Skipjack Tuna, Katsuwonus pelamis (NOAA, United States, 1984)

17. P. A. R. P. Tampubolon, I. Jatmiko, H. Hartaty, A. Bahtiar, IOTC-2014-WPTT16-35, Reproductive biology of skipjack tuna (Katsuwonus pelamis) in Eastern Indian Ocean. (IOTC, Victoria, Seychelles, 2014)

18. A. Wujdi, I. Jatmiko, B. Setyadji, R. K. Sulistyaningsih, D. Novianto, F. Rochman, A. Bahtiar, H. Hartaty, IOTC-2014-WPTT16-44, Distribution and biological aspect of yellowfin tuna (Thunnus albacares) caught by Indonesian tuna longline in the Eastern Indian Ocean (IOTC, Victoria, Seychelles, 2014)

19. K. P. S. Koya, U. Ganga, J. Jayasankar, R. Gireesh, T. B. Retheesh, R. Thangaraja, E. M. Abdussamad, Indian J. Fish., 60, 3, 119-122 (2013)

20. A. T. Reyes, L. J. Fajardo, D. P Saludo, Acta Entomology and Zoology 2021; 2, 1 (2021)

21. K. Mimura, Staff. Synopsis on the biology of bigeye tuna Parathunnus mebachi Kishinouye 1923 (Indian Ocean) (FAO, Rome, 1965).

22. R. Faizah, B. I. Prisantoso, Bawal, 3, 2 (2010)

23. B. Setyadji, A. Bahtiar, B. Nugraha, Widyariset, 15, 3 (2012)

24. G. L. Arnenda, B. Setiyadi, N. I. Wiratmini, I. M. S. Wijana, Saintek Perikanan, 16, 3 (2020)

25. M. G. Johnson, A. R. Tamatamah, Pak J. Biol. Sci, 16 (2013)

26. K. Wagiyo, E. Febrianti, Bawal, 7, 2 (2015)

27. S. P Griffiths, D. Leadbitter. D. Willette, F. Kaymaram . M. Moazzam, Rev Fish. Biol. Fisheries (2019)

28. V. K. Mudumala, M. K. Farejiya, K. S. Mali, K. C. Sahu, R. Tailor, Int J. Fish Aquat. Stud., 5, 2 (2017)

29. J. Martínez-Ortiz, A. M. Aires-da-Silva, C. E. Lennert-Cody, M. N. Maunder, PLoS ONE 10, 8 (2015).

30. M. Yesaki, Rainbow Runner: A Latent Oceanic Resource Marine Fisheries Review (1979)

31. F. Schwartz, J N C Acad Sci, 120, 3 (2004)

32. I. Nakamura, Billfishes of the world. An annotated and illustrated catalogue of marlins, sailfishes, spearfishes and swordfishes kwon to date (FAO, Rome, 1985)

33. S. M. Williams, PhD Thesis. The global biology, ecology and phylogenetic status of black marlin (Istiompax indica). Australia: University of Queensland (2018)

34. Dharmadi, Mahiswara, K. Kasim, Ind. Fish. Res. J. 22, 2 (2016)

35. H. Murua, J. Santiago, R. Coelho, I. Zudaire, C. Neves, D. Rosa., I. Zudaire, Y. Semba, Z. Geng, P. Bach, H. Arrizabalaga, P. Bach, J. C. Baez, M. L. Ramos, J. F Zhu, J. Ruiz, IOTC-2018-SC21-14_Rev1, Updated ecological risk assessment (era) for shark species caught in fisheries managed by the indian ocean tuna commission (IOTC, 2018) 
36. W. S. Patrick, P. Spencer, O. Ormseth, J. Cope, J. Field, D. Kobayashi, T. Gedamke, E. Cortés, K. Bigelow, W. Overholtz, J. Link, P. Lawson, Use of productivity and susceptibility indices to determine stock vulnerability, with example applications to six U.S. fisheries (NOAA, United States, 2009)

37. IOTC. Executive Summary: Skipjack Tuna (2020)

38. B. Setyadji, T. A. Wibawa, Z. Fahmi, IOTC-2018-WPB16-12, Catch per unit of effort (CPUE) standardization of black marlin (Makaira indica) caught by Indonesian tuna longline fishery in the Eastern Indian Ocean (IOTC, 2018)

39. D. B. Thompson, M. Ben-Yami, Fishing gear selectivity performance (FAO, Rome, 1983)

40. B. Wibowo, M. F. A. Sondita, B. H. Iskandar, J. Haluan, D. A. Soeboer, AACL Bioflux, 2018, 11, 1, 8 (2018)

41. W. S. Patrick, Spencer, J. Link, J. Cope, J. Field, D. Kobayashi, W. Overholtz, Fishery Bulletin, 108 (2010)

42. Hobday, A. D. M. Smith, I. C. Stobutzki, C. Bulman, R. Daley, J. M. Dambacher, R. A. Deng J. Dowdney, M. Fuller, D. Furlani, S.P. Griffiths, D. Johnson, R. Kenyon, I.A. Knuckey, S.D. Ling, R. Pitcher, K. J. Sainsbury, M. Sporcic, T. Smith, C. Turnbull, T.I. Walker f, S.E. Wayte, H. Webb, A. Williams, B.S. Wise, S. Zhou, Fish. Res. 108, (2011) 